\title{
Eliza Czapska*
}

\section{ROZMOWA WLADYSLAWA BRONIEWSKIEGO Z HISTORIĄ. MITY I ROLE ARTYSTY W SYMBOLICZNYM IMAGINARIUM POLSKI}

\begin{abstract}
Abstrakt. Artykuł dotyczy życia i twórczości Władysława Broniewskiego, poety, którego głos silnie zaznaczył się w historii Polski okresu międzywojennego i czasów PRL. Ukazuje rolę artysty i różne funkcje jego poezji w dwudziestoleciu międzywojennym oraz w następnych latach - podczas II wojny światowej oraz w nowym krajobrazie społecznym PRL, aż po współczesność. Powikłana droga twórcza i życiowa Broniewskiego omówiona została w szerokim kontekście mitów artystycznych.

Słowa kluczowe: Władysław Broniewski, historia, Polska, tragizm, poezja, romantyzm, tradycja, rodzina, patriotyzm, lewicowość, Legiony, I wojna światowa, międzywojnie, II wojna światowa, PRL, imaginarium, mity i role artysty.
\end{abstract}

\section{Wprowadzenie}

Celem niniejszego tekstu jest próba ujęcia sylwetki i roli poety Władysława Broniewskiego w kontekście kategorii legendy artystycznej, mitu w rozumieniu Mariana Golki (2012). Autorka z pozycji socjologiczno-historycznej stara się wyodrębnić role „naczelnego poety” PRL, dziś już klasyka, a także odsłonić postawę twórczą i życiową poprzez rekonstrukcję wydarzeń historycznych i życiowych oraz analizę twórczości. Opiera się na materiałach archiwalnych pochodzących z Muzeum Władysława Broniewskiego oraz wybranej literaturze popularnej, takiej, która funkcjonuje w najszerszym obiegu społecznym ${ }^{1}$. Autorka nie uwzględnia całej bibliografii przedmiotu (kwerenda biblioteczna), nie rozstrzyga, co jest prawdą obiektywną, a co nie. Jako kierownik Muzeum Władysława Broniewskiego posiada natomiast dostęp do nieopublikowanych materiałów (jak wspomnienia, listy, rozmowy, wywiady z członkami rodziny, przyjaciółmi poety). Częściowo wiedzę tę wykorzystuje w prezentowanym tekście. Osobowość

\footnotetext{
* Muzeum Literatury im. Adama Mickiewicza, Oddział Muzeum Władysława Broniewskiego

${ }^{1}$ Choć trzeba przyznać, że często zawiera ona informacje z drugiej lub trzeciej ręki.
} 
twórcza i biografia poety umieszczone zostają w perspektywie skrzyżowania wielu odczytań biografii, wspomnień w kategoriach mitów artystycznych, np. cierpienia, zaangażowania, indywidualności, mitu samotności, spontaniczności, odrzucenia, buntu (zob. Wejbert-Wąsiewicz 2009). Ponadto autorka poprzez życiorys poety ogląda Historię i Czasy, bowiem burzliwe losy Broniewskiego, język, światopoglądowe i duchowe rozterki, jak w soczewce pokazują skomplikowaną historię Polski ostatniego stulecia ${ }^{2}$. Wydaje się, że żaden inny poeta współczesny nie był tak jak Broniewski sprzęgnięty z wydarzeniami czasu historycznego. Jego droga ideowa wyrażała do pewnego stopnia prawidłowość przemian młodej polskiej inteligencji (por. Pryzwan 2011: 53). Prezentowane case study posiada także charakter refleksyjny w obliczu świętowania setnej rocznicy odzyskania niepodległości.

Karty historii sztuki wypełniają nazwiska tylko tych artystów, którzy zdobyli status klasyka (Golka 2012). Wydanie przez Ossolineum w roku 2016 w Bibliotece Narodowej wyboru wierszy Władysława Broniewskiego dowodzi, że poeta dorobił się tego miana. Zważywszy na kilka dziesięcioleci po II wojnie światowej, kiedy to Broniewski uważany był za pierwszego poetę w kraju, a także idące w setki tysięcy egzemplarzy wydania jego wierszy, może budzić zdziwienie fakt późnego wydania go w prestiżowej serii Klasyków Literatury Polskiej. $\mathrm{Z}$ drugiej strony dopiero teraz, kiedy kolejne karty życiorysu Broniewskiego zostają odkrywane ${ }^{3}$, poeta, pozbywszy się nimbu monolitu, może zyskać status klasyka.

\section{Indywidualista i świadomy artysta}

W życiu i twórczości poety silnie zaznaczył się indywidualny rys. Ceną, jaką płaci artysta za bycie autentycznym i oryginalnym, jest to, że często musi się odsłonić, odkryć, ukazać intymne swe wnętrze, ale także stawać się własnym promotorem, walczyć o pozycję w świecie artystycznym. Broniewski wykazywał na tym polu wyjątkową zapobiegliwość. Zbierał wszelkie możliwe dokumenty związane z własną osobą, skrzętnie przechowywał rękopisy swoich utworów, korespondencję od rodziny i przyjaciół, rachunki, bilety wizytowe, dokumenty wojskowe. „Dziwnym, szczęśliwym trafem, pomimo katastrof wojennych, zachowały mi się prawie wszystkie rękopisy, które oddałem pod opiekę mojej żony i Instytutu Badań Literackich” - wspominał („Express Wieczorny” 1960). Po uwięzieniu w Oświęcimiu drugiej żony poety, Marii Zarębińskiej, archiwum Broniewskiego

${ }^{2}$ W wierszu Do poezji Broniewski głosił: „Moje życie podobne lustru,/ w którym zły przegląda się los./ Każde prawo i każdy ustrój/ w całopalny rzuca mnie stos" (Broniew ski 2016: 95).

${ }^{3}$ W ciągu ostatnich kilku lat wydano po raz pierwszy w wersji nieocenzurowanej Pamiętnik Broniewskiego z lat 1918-1922, listy do żon - Janiny Broniewskiej i Wandy Broniewskiej, Publicystykę, Prozę (w Wydawnictwie Krytyki Politycznej), korespondencję z przyjaciółką Ireną Hellma. 
pozostało w żoliborskim domu jej ojca. Po wojnie jako pierwsza z rodziny przybyła do Warszawy Janina Broniewska i szczęśliwie odnalazła je w śniegu wraz z wyrzuconym na ulicę biurkiem poety. Dziś te rękopisy i dokumenty stanowią archiwalne zbiory Muzeum Władysława Broniewskiego.

\section{Broniewski i powojenne imaginarium Polski a współczesny status poety}

Artystę należy rozpatrywać w powiązaniu z odbiorcą jego twórczości. Przypadek Władysława Broniewskiego jest tu wymowny. Niektóre jego wiersze z pierwszego, międzywojennego okresu twórczości do tego stopnia weszły do czytelniczego obiegu, że zyskały bezimienność, „trafiły pod strzechy”, o czym marzyli romantycy. Stały się wspólną, znaną przez ogół pieśnią. Okres II wojny światowej przyniósł utwory, które zyskały status apelu, wezwania, dodawały Polakom otuchy i odwagi. Wypada zauważyć, że zabiegi cenzorskie nie przeszkodziły poezji Broniewskiego w czynnym funkcjonowaniu wśród odbiorców, a aura utworu zakazanego wzmacniała jeszcze ich treść. Po II wojnie twórca został namaszczony na pierwszego poetę w kraju, zyskując za życia masowe grono odbiorców, nieporównywalne z jakimkolwiek artystą w historii polskiej literatury. Trudna sytuacja społeczna ogromnej rzeszy Polaków zmęczonych doświadczeniami wojny, materialna odbudowa zniszczonego kraju, procesy demokratyzacji wymagały głosu, który przemówi w imieniu nowych obywateli, dostarczy im językowych narzędzi afirmujących wprowadzany ład, zachęci do zaangażowania się oraz usankcjonuje wprowadzane zmiany. Talent i żywioł artysty Broniewskiego skutecznie i na szeroką skalę zostały wprzęgnięte w misję kształtowania owego nowego, powojennego, symbolicznego imaginarium komunizmu oraz $\mathrm{w}$ dia$\log$ z człowiekiem dotąd krzywdzonym.

Opisy pierwszych spotkań twórcy z publicznością w Polsce pokazują, jak wielką wartość stanowiło dla znękanych wojną ludzi słowo poety ${ }^{4}$. Liczne listy od wielbicieli przechowywane w Muzeum Władysława Broniewskiego udowadniają, jaką rolę dla masowego odbiorcy pełnił artysta przez kolejne dziesięciolecia. Pisali do niego robotnicy, studenci, nauczyciele, dzieci. Broniewski często wyjeżdżał na kilkudniowe, a nawet dwutygodniowe „tournée” po Polsce, które nazywał

\footnotetext{
${ }^{4}$ Seweryna Szmaglewska wspomina: „Początek roku 1946, Pałac Poznańskich w Łodzi wypełniony do ostatniego miejsca w obszernej Sali, a także po brzegi korytarzy, schodów, przedsionków i sieni; woźny walczy z napierającym tłumem, usiłując przytrzymać od środka rozfalowane drzwi. Ludzie wówczas nie domagali się tak gwałtownie chleba i mięsa jak poezji, żywego słowa, rozmowy z pisarzem. [...] Władysław Broniewski powrócił właśnie do kraju ze swojej wojennej tułaczki. W atmosferze głodu doznań artystycznych sala chłonęła bez tchu każde zdanie, wypijała je ufna, że pisarz powie coś najistotniejszego, na co się czekało przez lata hitlerowskiej okupacji" (Pryzwan 2011: 127).
} 
objazdami duszpasterskimi. Codziennie odbywał kilka spotkań w domach kultury, fabrykach, zakładach. Był eksploatowany ponad miarę5.

Po okresie ogromnej popularności, kiedy to słuchacze poezji Broniewskiego licznie zapełniali sale domów kultury i fabryk, przyszła transformacja 1989 roku. Jego postać, kojarzona z minioną epoką, miała odejść w zapomnienie ${ }^{6}$. Społeczne wyobrażenia na temat Władysława Broniewskiego pełne stereotypów, kalek, przemilczeń, wzięły górę nad jego prawdziwym wizerunkiem i faktyczną wartością dzieł. Wydaje się jednak, że artysta Broniewski przetrwał kolejne zakręty historii, a jego uwikłanie w czasy, politykę, rozbudziło na nowo zainteresowanie tą postacią. Wydanie biografii Broniewskiego autorstwa Mariusza Urbanka, spektakl Teatru Wybrzeże pt. Broniewski wystawiany z powodzeniem w całej Polsce, obraz przedstawiający Broniewskiego namalowany przez najsłynniejszego współczesnego malarza polskiego Wilhelma Sasnala przy okazji głośnego projektu Galerii Raster pt. Broniewski, a także liczne powstające wciąż utwory muzyczne do jego wierszy dowodzą, że Broniewski jest wciąż żywy w obiegu kulturowym. A wkroczył do niego głośno, raźnym, żołnierskim krokiem.

\section{Patriotyzm i powolanie artysty}

Pierwsze dziecięce literackie próby i rysunki poety pokazują, że wrażliwy chłopiec od wczesnych lat wykazywał artystyczne skłonności ${ }^{7}$. Broniewski pod koniec życia wspominał, jak babcia uczyła go grać na pianinie utwory Chopina ${ }^{8}$. Ogromny wpływ na rozwój jego artystycznego powołania z pewnością miała również atmosfera szkoły, do której uczęszczał. W odróżnieniu od innych szkół w zaborze rosyjskim, w Jagiellonce wykładano po polsku. Broniewski ze szczególnym rozrzewnieniem wspominał po latach nauczyciela języka polskiego, który rozbudzał i pielęgnował w uczniach miłość do literatury. Szybko sam chciał się

${ }^{5}$ Mówił w jednym z wywiadów: „Piszę mało, publikuję niewiele, za to bardzo często jeżdżę na spotkania z czytelnikami po całym kraju. Takich bezpośrednich spotkań z czytelnikami, wieczorów autorskich miałem już około trzech tysięcy” („Express Wieczorny” 1960).

${ }^{6}$ „Czyściec” Broniewskiego w pierwszych latach po upadku PRL przejawił się w nieprzezwyciężonych do pewnego czasu trudnościach, jakie napotykała publikacja krytycznego wydania jego wszystkich wierszy, przygotowanego przez najwybitniejszą badaczkę jego twórczości Feliksę Lichodziejewską (Pryzwan 2011: 163).

7 „Przepowiadano mu, że będzie malarzem, bo rysował jako tako, że aktorem, bo deklamował ślicznie wiersze pani Konopnickiej, a koniec tym przepowiedniom położyła babka, bo chłopczyk miał słuch" (Broniew ski 2013: 207). Babka ubolewała potem nad brakiem wyboru konkretnego zawodu przez ukochanego wnuka.

${ }^{8}$ Być może jako nauczycielka gry na pianinie wywarła największy wpływ na przyszłe powołanie Broniewskiego jako artysty. „Przez całe moje życie przesuwa się Mazurek h-moll. Pomyślałem, że mazurek można wyrazić słowami. I z tego punktu właściwie zaczęła się moja poezja” (Broniewski 2013: 218). 
sprawdzić w pisaniu, inicjując redagowanie szkolnej gazetki „Młodzi idą”. Zapełniał jej kolumny właściwie samodzielnie, publikując pod różnymi pseudonimami artykuły dotyczące kwestii niepodległości i postulujące równość obywatelską. Artystyczną wrażliwość rozwijało też w Broniewskim obserwowanie wyjątkowo malowniczych krajobrazów ziemi rodzinnej. Kto oglądał Wisłę z płockiej skarpy, wie, że widok ten można porównać z niewieloma wiślanymi pejzażami w Polsce9. Trzeba podkreślić, że atmosfera jego rodzinnego domu wypełniona była kultem polskości, niezwykle żywy w nim był etos intelektualny, patriotyczny i niepodległościowy. Lektury romantyków marzących o wolnej Polsce, utwory Chopina grane przez babcię, kult braci babki, którzy zginęli w 1863 roku, nostalgiczne krajobrazy kraju lat dziecinnych (meandry Wisły widziane z ogrodu domu w Płocku) - wszystko to zbudowało w nim silną tożsamość narodową. Na zew bojowy Broniewski odpowiedział i jako żołnierz, i jako artysta.

W kwietniu 1915 roku wraz z grupą kolegów z płockiego Gimnazjum im. Władysława Jagiełly stanął o świcie przed katedrą na tumskim wzgórzu, by przeprawić się tratwą do Włocławka, gdzie stacjonowali legioniści. Siedemnastoletni przyszli żołnierze, w kompletnej ciszy, nieżegnani przez nikogo, pomaszerowali w dół nad Wisłę. Przeciwne tej decyzji i zmartwione pozostawały matka ${ }^{10} \mathrm{i}$ babcia, które wspólnie wychowywały Władzia (ojciec Broniewskiego zmarł, gdy chłopiec miał pięć lat). Po latach traumatyczne przeżycia wojenne Broniewski $\mathrm{z}$ sukcesem zamknął $\mathrm{w}$ artystycznej formie.

Władysław Broniewski zasilając szeregi Legionów, okazał się świetnym żołnierzem. Dowodził kompanią wpatrzonych w niego z uwielbieniem żołnierzy. Otrzymał krzyż Virtuti Militari i trzy Krzyże Walecznych, a zdobył je jako oficer liniowy - w ogniu. W okresie wojskowym sięgał po pióro. Od 1918 roku zaczął pisać pamiętnik. W niepodległej Polsce Piłsudczycy obsadzani byli na intratnych urzędniczych stanowiskach w administracji rządowej i lokalnej. Broniewski czuł jednak w sobie powołanie artysty, więc zrezygnował z kariery wojskowej ${ }^{11}$, choć ta pozostawała łatwiejszą drogą życiową niż niejasny los literata.

${ }^{9}$ Władysław Broniewski, wychowany w płockim domu na wzgórzu (na ulicy Kościuszki), karmił swoją artystyczną wyobraźnię jego pięknem na co dzień. W zmysłowym odbiorze świata pomagała mu też zaprzyjaźniona z rodziną pani Tańska, która pytała przyszłego poetę: „Słyszysz, jak te drzewa szumią? Zdanie to zapamiętał na całe życie, jak wspominał (B ro ni ew ski 2013: 216). Rodzinnym krajobrazom poświęcił wiele wierszy, które do dziś stanowią stały element mitologii Płocka.

${ }^{10}$ Pod koniec życia tak wspominał matkę: ,Moja matka nie była żadnym okazem spośród tysięcy podobnych panien czy mężatek. Ale ona czytała Spencera i jeszcze jakichś Anglików i dała mi na całe życie, poza dziesięcioma przykazaniami, których mnie tam nauczono, jedno przykazanie: Self help. Sam sobie pomóż. Ja to przykazanie za wcześnie zrozumiałem i może dlatego za wcześnie ruszyłem na wojnę" (Broniew ski 2013: 212).

${ }^{11}$ Pisał o tym do kuzynki Halszki Kamockiej: „A już niedługo rzucę mundur i przyjadę do Warszawy utonąć w morzu jakiejś czytelni. Dławię się potrzebą pisania, ale tak mi się wszystko wizyjnie w mózg wtłacza, że nie mogę nic, czekam. Dramat układam - czy nie w swoim życiu? 
Debiutancki zbiór wierszy Broniewskiego wydanych w 1925 roku pt. Wiatraki postawił go w szeregu najzdolniejszych twórców swojego pokolenia. Osiemnaście wierszy tomu wybrzmiało z ogromną siłą, a najdobitniej te, które opowiadały o ostatniej wojnie, pokazując okrutną codzienność, śmierć tysięcy młodych chłopców, którzy tak jak autor chwycili za karabin i ruszyli, by walczyć w okopach, gdzie leżały trupy ich niedawnych jeszcze kompanów.

\section{Mit cierpienia}

W biografii Broniewskiego dość szybko pojawił się mit cierpienia ${ }^{12}$. Ta postawa, polegająca na swoistym odkupieniu świata poprzez własny ból, uznawana bywa często za niezbędny element w życiu artysty (Golka 2012). Nawiązuje także do tradycyjnego motywu Chrystusowego. Broniewski był postrzegany poprzez cierpienie własne i człowiecze ${ }^{13}$.

W przypadku Broniewskiego cierpienie opisywane w najwcześniejszych wierszach było nie literacką kreacją, ale autentycznym bólem zrodzonym z traumy wojennej. Obecne w wierszu-arcydziele pt. Listopady dekadenckie niepokoje egzystencjalne, refleksje o grozie i absurdzie istnienia, mają więc podłoże nie tylko w rozedrganym wnętrzu poety, ale żywią się przeżytą, straszną rzeczywistością ${ }^{14}$. Cierpienie prowadzące aż do śmierci było udziałem innego poety, którego Broniewski szczególnie wielbił. Jesieninowi, bo o niego tu chodzi, poświęcił przejmujący wiersz pt. Nocny gość, gdzie z mistrzostwem opisał zgrozę rzekomego samobójstwa, jakie popełnił wielki rosyjski poeta. Ciosy zadawała poecie Historia w postaci licznych doświadczeń więziennych. Na początku był to obóz

Pogrzebawszy swą górną i chmurną przeszłość, rozpoczynam wszystko jak maturzysta" (z archiwum Muzeum Władysława Broniewskiego).

12 „Koszmar przeżyć wielkiej rzezi europejskiej wbił głęboko pazury w mózg poety i zabarwił ciemną pożogą wszystkie jego wizje” - zauważał w „Wiadomościach” Witold Wandurski (Urbanek 2011: 58). A sam poeta w wierszu Młodość pisał: „Roztapiała się młodość brudnym, mokrym śniegiem,/ Dławiły dni pochmurne, jak robactwo żarły,/ I już mi chłodne były jesienne noclegi,/ I z umarłymi byłem sam na pół martwy" (Broniewski 2016: 45).

13 Giennadij Ajgi, rosyjski poeta i tłumacz, tak mówił o poecie: „On mi przypomina, że przeznaczeniem poety jest zaznanie najwyższego tragizmu na samym sobie, że to w ogóle jego posłannictwo - wziąć na siebie tragizm człowieczego istnienia i wyrażać poprzez siebie, wcielić w słowo to ogromne cierpienie, tragizm wielu ludzi i płacić za to" (U rb an ek 2011: 88). Jarosław Iwaszkiewicz dziesięć lat po śmierci poety, na łamach nowo powstałego pisma „Literatura”, stwierdził: „Broniewski umiał cierpieć, a cierpień w swym życiu miał niemało. Dlatego jego wiersze brzmią czysto jak spiż dzwonów i nieprzemijający jest czar jego głębokiej poezji” („Literatura” 1972). A tonem już mniej oficjalnym na wieść o śmierci autora Troski i pieśni powiedział: „Skończyło się to nieszczęśliwe życie..." (Urbanek 2011: 288).

14 „Całe życie zrywam się i padam,/ Jakbym w piersi miał wiatr na uwięzi,/ I chwytają mnie złe listopady/ Czarnymi palcami gałęzi./ [...] Jak błękitny płomień alkoholu,/ Płoniesz we mnie moje nieszczęście. [...]/ Muszę chodzić, muszę męczyć się wiecznie" (Broniew ski 2016: 38). 
jeniecki w Szczypiornie, potem więzienie sanackie w 1931 roku, kiedy Broniewski został aresztowany wraz z innymi redaktorami lewicowego „Miesięcznika”, i w końcu najcięższe więzienie NKWD, gdzie trafił wraz z Aleksandrem Watem aresztowany w 1940 roku we Lwowie z powodu zbytniego manifestowania polskości. Odbył półtoraroczną zsyłkę (Zamarstynów, Łubianka, Ałma Ata), w czasie której bity stracił zęby i zdrowie. Cierpienie zaznane w więzieniu NKWD nie złamało go jednak. Aleksander Wat wspominał o niezwykłym harcie ciała i ducha poety, który całymi dniami maszerował po celi, śpiewając legionowe pieśni ${ }^{15}$. Natomiast osobiste i najbardziej tragiczne przeżycia poeta ukazał w intymnych wierszach. Doświadczył śmierci najlepszej przyjaciółki, ukochanej żony Marii Zarębińskiej nie raz, a dwa razy. Pierwsza, fałszywa informacja o śmierci Marii w Oświęcimiu, dotarła do poety w Palestynie. Wywołała w nim rozpacz, której dał wyraz w tomie wierszy pt. Drzewo rozpaczajace. Z kolei radość z przeżytej wspólnie wojny szybko miała jednak ustąpić mającemu się znów powtórzyć cierpieniu - w 1947 roku Maria zmarła w Zurychu.

Najboleśniejszym doświadczeniem w życiu poety była tragiczna śmierć ukochanej i jedynej rodzonej córki, Anki, w 1954 roku. Odtąd zrozpaczony poeta szukał coraz częściej ucieczki w alkoholu, a w nocy pisał wiersze pełne ojcowskiego bólu. W nocy też często recytował je przez telefon znajomym, zazwyczaj niezachwyconym tym faktem ${ }^{16}$. Gdy Jarosław Iwaszkiewicz jako prezes Związku Literatów Polskich miał wydać opinię o trenach Anka, zdziwił go stopień obnażenia się poety ze swoim bólem przed czytelnikiem. Wiersze wydały mu się niedyskretne, pozbawione finalnego "maestoso" występującego we wzorcowych trenach Kochanowskiego. Wkrótce jednak docenił pełne bólu, „wichrem targane wiersze", pisane przez zrozpaczonego ojca (Urbanek 2011: 233). To odejście od dotychczasowych konwencji literackich, złamanie zasady decorum pokazuje bunt poety, który dotyczył także formy tworzonych przez niego dzieł.

\section{Buntownik z wielu powodów}

Najistotniejszy bunt w życiu Broniewskiego wziął się z wrażliwości społecznej artysty. Poeta posiadał silny zmysł społeczny, wrażliwość, o której za czasów jego młodości mówiło się „rodem z żeromszczyzny”. Występował przeciw zastanemu porządkowi w imię wyższych wartości, stając się buntownikiem walczącym

15 „Władzio był niesłychanie dzielny, z ogromną siłą, jakieś orlątko. I nie tylko w tym szczerze go podziwiałem. Chodził po celi żołnierskim krokiem, wybijał takt i śpiewał wszystkie legionowe pieśni. Cały czas śpiewał, pięć dób śpiewał. Dał mi po prostu pokaz, jak można zachować godność ludzką, siłę i bojowość. Nie widziałem lepszej, godniejszej postawy niż ta, którą miał wtedy Broniewski" (Urbanek 2011: 86).

16 Danuta Słoboda wspominała: „Mimo zrozumienia jego cierpienia i rozpaczy, było to bardzo uciążliwe. Wyrywało ze snu i nastrajało głębokim smutkiem. Broniewski płakał i recytował. Głosem ochrypniętym, przerywanym, niewyraźnym" (Pryzw an 2011: 192). 
o uciśnione masy. Widział i odczuwał przedwojenny świat biedy i nędzy i czuł się odpowiedzialny ${ }^{17}$. A bieda przedwojenna w poszczególnych częściach dawnych zaborów po odzyskaniu niepodległości zamieniła się w biedę polską. Kształtująca się w niepodległym kraju lewica ${ }^{18}$ broniła etosu pracowniczego i negowała panujące stosunki społeczne. Drugi w jego karierze tom, Trzy salwy, współtworzył z Witoldem Wandurskim i Ryszardem Standem - literatami silnie zaangażowanymi w idee komunizmu. Ich wiersze miały być manifestacjami społeczno-politycznymi, gotową wypowiedzią robotników, którzy tym sposobem zyskiwali swoich trybunów. Wandurski mieszkał w Łodzi ${ }^{19}$, gdzie mijał na ulicach wyczerpanych pracą ponad siły robotników.

Poglądy młodego Broniewskiego zaczęły się radykalizować pod wpływem dramatycznych wydarzeń mających miejsce w wolnej, ale skłóconej ojczyźnie, których kulminacją stał się zamach na pierwszego prezydenta Polski w grudniu 1922 roku. Wierzył on jednak jeszcze, że za rządów Piłsudskiego Polska zyska kształt, o jaki walczył (sprawiedliwej i demokratycznej). W roku 1926 wziął udział w przewrocie majowym, co później podsumował - „Uległem, jak wielu, złudzeniu, że zmieni się coś w Polsce w duchu demokratycznym, rewolucyjnym" (Urbanek 2011: 66). Krwawe sthumienie manifestacji antyrządowej w 1928 roku na Placu Teatralnym ostatecznie rozwiało jego złudzenia ${ }^{20}$. Broniewski jako były legionista wziął rozbrat z rządzącą w Polsce sanacją. Szokujące i tragiczne wydarzenie opisał w Balladzie o Placu Teatralnym. Smutna ballada o bratobójstwie wybrzmiewała obok innych wierszy trzeciego tomiku pt. Troska i pieśńn, w których poeta buntował się przeciw rzeczywistości. W utworze Do towarzyszy broni (Broniewski 2016: 45) wzywał byłych kompanów z Legionów do otwarcia bram więzień politycznych. Dla uwięzionych tam osób wiersze Broniewskiego były ogromnym wsparciem, przemycano je do cel w postaci grypsów, uczono się ich na pamięć.

Inteligenckie poczucie odpowiedzialności prowadziło Broniewskiego nie tylko do wskazywania problemów społecznych, rzucania na nie światła poezji, ale przede wszystkim rodziło pragnienie, by swoją twórczością, jak kiedyś karabinem, doprowadzić do zmiany status quo ${ }^{21}$.

${ }^{17}$ Pracujący razem z Broniewskim w „Wiadomościach Literackich” Stefan Napierski skomplementował poetę - „Pan ma to, czego w Polsce i w grupie Skamandra dotkliwie brakuje - poczucie odpowiedzialności” (Urbanek 2011: 64).

${ }^{18}$ „Jeśli lewica może być patriotyczna, to tylko przez krytykę słabości i zakłamań wspólnoty, w której żyje. Lukrowanie narodu jest charakterystyczne dla myśli endeckiej” - postulowano (S hore 2013: 187).

19 Jak podaje Opis miasta Łodzi, ich sytuacja socjalna i tak poprawiła się od czasu, kiedy pracowali na wsiach jako najemni chłopi (Flatt 2011).

${ }^{20}$ „Ciała robotników zabitych przez policjantów, wspieranych przez członków PPS, z którymi być może jeszcze parę lat wcześniej bił się o Polskę, mocniej zapadały mu w pamięć niż ofiary wojny, w której uczestniczył" (Urbanek 2011: 79).

${ }^{21}$ W wierszu Do przyjaciót poetów z wydanego w 1938 roku tomu pt. Krzyk ostateczny pisał: „w blasku dni, które idą/, nasze słowa staną jak wojsko/ trzeba dziś je uzbroić, /jutro - dać im wielkość i sławę/ by się prawem stały i siłą" (Broniew ski 2016: 72). 


\section{Poeta zaangażowany, czyli glos skrzywdzonych}

Władysław Broniewski był twórcą zaangażowanym. Pracując w „Wiadomościach Literackich", piśmie uznawanym z dzisiejszej perspektywy za liberalne, występował jako głos budzącego się sumienia społeczeństwa, trybun robotników. Dla wyrażenia poczucia krzywdy w Polsce międzywojennej nie wytworzył się język polityki, ale w twórczości Broniewskiego wyraźnie widać próby oddania tej krzywdy (Leder 2014). W jego wierszach powstałych w międzywojniu odnajdują własne przeżycia ci, którzy sami nie potrafili dać wyrazu swojej frustracjii ${ }^{22}$. Jest to przede wszystkim gniew wyzyskiwanych w fabrykach. A przy tym niejeden wiersz autora Krzyku ostatecznego, „wędrując pomiędzy ludźmi, zyskiwał sobie sławę największą; bezimienność, jaką mają ludowe pieśni” (za: Urbanek 2011: 94). Broniewski z humorem opowiedział kiedyś Monice Warneńskiej, jak po aresztowaniu w roku 1931, przebywając w celi więziennej, usłyszał piosenkę śpiewaną przez współtowarzyszy niedoli. Była to ,piosenka więzienna” pod tytułem Bezrobotny, rozpoczynająca się słowami: „Nie ma za co jeść i pić”, którą on sam napisał w 1928 roku. Śpiewający przekręcali słowa piosenki, więc Broniewski zareagował: „Gdy im o tym powiedziałem, spojrzeli na mnie pobłażliwie. Wreszcie jeden rzekł: E, co wy tam się na tym znacie, towarzyszu! To przecież nasza więzienna piosenka i my dobrze wiemy, jak ją śpiewać!" (Broniewski 2016: 134).

Artysta zaangażowany to taki, który pragnie uczestniczyć w tworzeniu nowego porządku społecznego, a jego sztuka ma służyć wzniosłym celom, walczyć w słusznej sprawie (por. Golka 2012; Wejbert-Wąsiewicz 2009). Wiersze Broniewskiego edukowały, umacniały klasę robotniczą. Z nich dowiadywano się o Ludwiku Waryńskim (Elegia o śmierci Ludwika Waryńskiego), o tym, czym była Komuna Paryska, o strajkach w Zagłębiu Dąbrowskim i Łodzi (wiersze z tomu pt. Troska i pieśń, opublikowanego w 1932 roku). Emocje, pragnienia i potrzeby robotników ${ }^{23}$, które znalazły wyraz w wierszach Broniewskiego, stawały się własnością ogółu ${ }^{24}$. Rewolucyjne idee i postaci komponowały się ze szczerością postawy twórczej25.

${ }^{22}$ Według Ledera, zmiany zachodzące w społeczeństwie w dwudziestoleciu międzywojennym pozwalały co prawda „formować się i krzepnąc chłopskim oraz lewicowym ruchom politycznych, które mocno i aktywnie wyrażały swój bunt i protest przeciwko międzywojennej hierarchii społecznej. Można jednak podejrzewać, że wiele złych intencji i pragnień nie znajdowało ekspresji politycznej" (Leder 2015: 134).

${ }^{23}$ „«Wrażliwość Broniewskiego na podłość, nikczemność i łajdactwo ustroju kapitalistycznego jest niewyczerpana» - pisał Marian Czuchnowski na łamach lewicowego pisma «Czarno na białem», nazywając go poetą szturmowym uświadomionych robotników" (Urbanek 2011: 140).

${ }^{24}$ „Poezja Broniewskiego była dla nas pierwszym podręcznikiem dziejów i pierwszym zbiorem zasad ruchu rewolucyjnego" - wspominał Ryszard Matuszewski (Pry zw an 2011: 127).

${ }^{25}$ Zdaniem Czuchnowskiego, Broniewski miał nad całą plejadą poetów rewolucyjnych jedną niezaprzeczalną przewagę: pisał dobre, szczere, oryginalne, odrębne, wiarygodne wiersze. „Czy 


\section{Niepokorny romantyk wierny sobie}

Romantycznym koncepcjom artysty towarzyszyły, oprócz mitu indywidualności, odmienności, również mit wolności artystycznej oraz zaangażowania. Żarliwośćc ${ }^{26}$, pewność swego posłannictwa stawia Broniewskiego w rzędzie artystów o rodowodzie romantycznym. Lekceważył on cenzurę i zyskiwał tym samym sławę poety zakazanego. Część wierszy autora Ostatniej wojny dostępna była jedynie w podziemnym obiegu. Poeta obawiał się jednak nie tylko nożyc oficjalnej cenzury, ale też nadgorliwości zaangażowanych w tę samą sprawę kolegów. Ci pouczali go, jak powinny wyglądać prawdziwe proletariackie wiersze. Badali, „,czy nie trącą drobnomieszczaństwem” (Urbanek 2011: 83). Przyjaciele, Wandurski i Stande, zaangażowani w działalność Komunistycznej Partii Polski, domagali się od Broniewskiego jednoznacznej deklaracji wstąpienia do partii oraz postulowali zmiany w utworach poety. W odpowiedzi Broniewski w wierszu pt. Przyjacielu, los nas poróżnit, skierowanym do Wandurskiego, pisał: „Nie pozwolę nikomu dotknąć/ harfy mej - ze stu żył - stustronnej,/ będę niósł ją - groźną, samotną - /choćby cięższa była od trumny" (Broniewski 2016: 69). Dostrzegano jego niepokorność, charyzmę, wierność sobie i ideałom ${ }^{27}$. Antoni Słonimski mówił o nim: „oficer Legionów Piłsudskiego, rewolucjonista z ducha, socjalista z najgłębszych przekonań, nie mieścił się w regułach ortodoksji" (Urbanek 2011: 99). Pojawia się tu interesująca kwestia przechodzenia Broniewskiego od jednej roli ${ }^{28}$ do innej, najczęściej sprzecznej. Już w międzywojniu musiał się nieraz thumaczyć z uczestnictwa w Legionach, które zaledwie dekadę wcześniej wywalczyły wolność w Polsce. Potęgowało to u poety poczucie samotności ${ }^{29}$.

Wieszczem z kolei okazał się w kwietniu 1939 roku, gdy opublikował w piśmie „Czarno na Białem” utwór pt. Bagnet na broń. Ten prorocki apel wzywał do

pisze o Zagłębiu, rewolucji, czy o irrealnej knajpie, jest zawsze sobą. Właśnie z powodu tej szczerości i słów, którym nie można zarzucić kłamstwa, chwytające za gardło wiersze Broniewskiego należą do najpopularniejszych w Polsce" (Pryzw an 2011: 142).

${ }^{26}$ We wspomnianym wierszu Do przyjaciót poetów Broniewski nawoływał: „mało nas... [...] my podpalacze serc,/ dynamitardzi sumień,/ recydywiści marzenia,/ gniewu i entuzjazmu./ Słowem nagim i skutym,/ jak Prometeusz na skale,/ świecimy nieustraszeni/ otchłaniom czasu pogardy. /Przyjdzie dzień,/ przyjdzie dzień,/ i radośnie będziemy podpalać!” (Broniew ski 2016: 43).

27 „Poeta jako były legionista i jako wierny duchowy spadkobierca domowych tradycji romantycznych i powstańczych był w ruchu rewolucyjnym lat międzywojennych czymś wyjątkowym nie tylko jako talent, ale jako rodzaj formacji psychosocjalnej" - mówił o nim Ryszard Matuszewski (Pryzwan 2011: 53).

28 „Rola pełniona jest w oparciu o więź, jaka się wytwarza w danej grupie i wskutek obecności w niej wspólnych wartości. Jednostka może bowiem grać swe role tylko we współpracy z tymi grupami i kręgami, a nawet wyłącznie przy ich akceptacji” (za: Golka 2012: 75).

29 „Wciąż musiał odpowiadać na pytania: Kim właściwie jest? I z kim tak naprawdę mu po drodze? A potem i tak nie chciano mu wierzyć" (Urbanek 2011: 83). 
walki za ojczyznę $e^{30}$. Jednakże kawaler Orderu Virtuti Militari, zdobywca czterech Krzyży Walecznych, żołnierz o niezwykłym talencie wojskowym, został pominięty przez sanację przy tworzeniu szeregów walczących z nazistowskim najeźdźcą. Wówczas we wrześniu 1939 roku samotnie ruszył na rowerze szukać swojego pułku.

Po wojnie Broniewski funkcjonował w różnych grupach oficjalnych i nieoficjalnych. W domach kultury, fabrykach, salonach rządowych pełnił rolę rewolucyjnego poety proletariatu. W swoim domu z kolei przyjmował przyjaciół legionistów, z którymi wspominał młodzieńcze lata walki w szeregach Piłsudskiego. Dziennik ${ }^{31}$ dwudziestodwuletniego młodego oficera przez długie lata traktowano jako niecenzuralny $\mathrm{z}$ wielu powodów. $\mathrm{W}$ okresie PRL wygrana $\mathrm{z}$ bolszewikami w 1920 roku musiała być przemilczana ${ }^{32}$, a kompani z Legionów mieli zapomnieć o swoim młodzieńczym zaangażowaniu. $\mathrm{W}$ domu poety przenikały się sprzeczne społeczne i polityczne światy ${ }^{33}$. To przenikanie się sprzecznych ról Broniewskiego zdarzało się również przy okazjach oficjalnych, na przykład podczas spotkań w Belwederze z prezydentem państwa ${ }^{34}$.

Broniewski był poetą i bojownikiem, świadomym swojej roli, niepokornym do końca. $\mathrm{W}$ testamentowym zapisie prosił, by na jego grobie umieścić napis: poeta i kapitan Wojsk Polskich. To życzenie umierającego poety nie mogło zostać spełnione w PRL, gdzie przecież funkcjonowało Wojsko Ludowe, zaś pamięć o Wojsku Polskim odwoływała się do legionowej przeszłości Broniewskiego, a ta nie istniała w jego oficjalnej biografii głoszonej przez panujący wówczas reżim. Poecie zabrano więc część biografii, pozostawiając tylko tę, która odpowiadała władzom PRL. Zadbano, by nawet podczas uroczystości pogrzebowych nie

30 Józef Hen wspominał, że w każdym wojskowym namiocie przypięta była strona $\mathrm{z}$ wierszem Broniewskiego. Bagnet na broń był na ustach wszystkich... (Urbanek 2011).

${ }^{31}$ „Władek lubił pokazywać przyjaciołom starannie strzeżony gruby notatnik, z dziennikiem własnoręcznie przez niego pisanym w czasie wojny polsko-bolszewickiej 1920 roku. Czasem czytał z niego pewne urywki, ale nie wypuszczał go z rąk" (Pryzw an 2011: 85).

${ }^{32}$ Broniewski prowadził wówczas do zwycięstwa wpatrzonych w niego z uwielbieniem żołnierzy.

${ }^{33}$ Ewa Fiszer wspominała: „W pamięci utkwiło mi wielkie przyjęcie w willi Broniewskiego, chyba z okazji urodzin. Było tam mnóstwo osób, sporo literatów, ale wielu nieznajomych. Następnego dnia mówiono w Warszawie, że byli tam kaci i ofiary. Był Michał Walicki, który niedawno wyszedł z więzienia, a ponoć było już kilku wysokich urzędników MSW" (Pryzwan 2011: 138).

34 Jedno z nich wspominał Matuszewski: „Było na tym belwederskim spotkaniu kilkudziesięciu autorów, czasem wysokiej rangi - Iwaszkiewicz, Dąbrowska itd. W pewnym momencie do Broniewskiego podszedł Bierut, gospodarz spotkania. Broniewski zadał mu wtedy pytanie świadczące o jego poczuciu wewnętrznej swobody; zapytał go wprost i tonem trochę zaczepnym, kiedy wreszcie będzie można pisać o jego przyjaciołach, Standem i Wandurskim. Rzecz polegała na tym, że wszystkim było wiadomo, iż o owych rozstrzelanych czy zamordowanych w sowieckich łagrach poetach nie mówi się i nie pisze, bo nie wolno. I oczywiście nikt inny takiego pytania Bierutowi nie miałby wtedy odwagi zadać, i to publicznie" (Pry zwan 2011: 57). 
znalazło się przemówienie pożegnalne ${ }^{35}$, które w imieniu Czwartaków miał wygłosić January Grzędziński - były legionista, redaktor międzywojennego pisma lewicowego. Dopiero Muzeum Władysława Broniewskiego spełniło wolę poety w 2016 roku.

Sądzę, że pomimo skomplikowanych związków Broniewskiego z władzą zachował on wolność artystyczną. Miał różne okresy depresji i załamań, ale zawsze pozostawał niezależny. Pisał to, co chciał pisać. Na zamówienie Bieruta na nowy hymn Polski: „Towarzyszu Broniewski, musi powstać nowy hymn. Napiszecie go wy, nasz wielki poeta”, Broniewski odpowiedział: „Zbyt drogi mi jest hymn Jeszcze Polska nie zginęła, żebym odważył się napisać cokolwiek innego!” (za: Urbanek 2011: 262). Przejawem wewnętrznej wolności poety była też sytuacja opisana przez Wiktora Woroszylskiego: „Kiedy to Broniewski już umierał i leżał w lecznicy rządowej, minister kultury przysłał mu bukiet kwiatów i bombonierkę. Broniewski odesłał prezenty, dołączając do nich bilecik: «Kwiaty proszę złożyć na grobie Stawara, a bombonierkę przekazać Kornackiemu»" (za: Pryzwan 2011: 120). Andrzej Stawar został wyklęty, gdy ogłosił przed śmiercią w paryskiej „Kulturze” teksty rewidujące dawne komunistyczne przekonania, a Jerzy Kornacki siedział w więzieniu. Ten gest Broniewskiego był szalenie wymowny. Również jego stosunek do tzw. sprawy żydowskiej nie mieścił się w popularnym nurcie światopoglądowym i odzwierciedlał jego wewnętrzną wolność oraz stawanie po stronie uciśnionych. Jako żołnierz armii Andersa, Broniewski protestował przeciw dyskryminacji Żydów podczas ewakuacji ludności cywilnej z Rosji, co zaowocowało zawieszeniem go w służbie czynnej (jak podawał Wiktor Weintraub, redaktor czasopisma „W Drodze”). Dla temperamentnego kapitana taki przymusowy stan spoczynku musiał być bolesny. Z kolei po zakończeniu II wojny, w maju 1946 roku Broniewski napisał wstęp ${ }^{36}$ do polskiego wydania $\mathrm{An}$ tysemity z przekonania francuskiego filozofa Juliana Bendy. Mówił o sprawach, które usiłowano wyprzeć z powszechnej pamięci. Zawstydzające fakty były jego zdaniem nie przejawem zwyrodnienia spowodowanego okupacją i zbrodniami hitlerowskimi, lecz wynikiem poglądów, które część polskiego społeczeństwa wyznaje od dawna ${ }^{37}$.

${ }^{35}$ Brzmiało ono: „Oto jesteśmy - pierwszych twych bojów towarzysze - nasze niesiemy ci serca w ich ogniu hartowane, niesiemy Ci żołnierski płaszcz z żołnierskich uczuć tkany. Kiedy będę umierać - mówiłeś - przyjaciele niech przyjdą narzucić na trupa żołnierski płaszcz... i niechaj wspomną moje żołnierstwo i niepodległą pieśn [...]” (z Archiwum Muzeum Władysława Broniewskiego).

${ }^{36}$ „Na szosach polskich dziś, po wielomilionowej masakrze Żydów dokonanej przez hitleryzm, polscy porucznicy Chenavard mordują Żydów" - pisał Broniewski dwa miesiące przed pogromem kieleckim.

37 „Bojkot ekonomiczny Żydów, działalność Falangi, ONR, podział obywateli II RP według kryteriów rasowych, wszystko to przygotowywało grunt pod wydarzenia, które nastąpiły później” (Urbanek 2011: 250). 


\section{Mit uznania czy odrzucenia?}

Wiele miejsca $\mathrm{w}$ dotychczasowych rozważaniach poświęciłam społecznej, buntowniczo-rewolucyjnej i zaangażowanej postawie Broniewskiego. Jest to obraz niepełny, brakuje w nim ukazania dążeń poety do zdobycia uznania i akceptacji społecznej Świadectwem uznania były niewątpliwie obchody dwudziestopięciolecia jego twórczości przypadające w 1950 roku. Hołdy dla niego spływały wówczas z różnych stron: depesze, listy gratulacyjne od najwyższych urzędników państwowych ${ }^{38}$, literatów, przyjaciół z różnych zakątków świata i ogromnej rzeszy czytelników z całego kraju. Można tu mówić o adoracji społecznej, która staje się udziałem wybitnych artystów. Przejawom prestiżu społecznego, sławy, powodzenia materialnego, uznania ze strony władzy towarzyszyło jednak niezadowolenie poety ze swojej pracy ${ }^{39}$. Częste kontakty z szerokim audytorium nie tłumiły niepokoju, który narastał w Broniewskim. Spragniony był indywidualnych rozmów, prywatnych opinii na temat własnej twórczości. Niepokój ten przybrał na sile szczególnie kilka lat po publikacji poematu pt. Słowo o Stalinie. Z okazji 70. urodzin Stalina w 1949 roku władze ogłosiły zamknięty konkurs, w którym wzięli udział literaci polscy, m.in.: Maria Dąbrowska, Zofia Nałkowska, Jarosław Iwaszkiewicz, Julian Tuwim, Konstanty Ildefons Gałczyński, Mieczysław Jastrun. Poemat Broniewskiego okazał się najlepszy. Zdaniem jego żony Wandy, pochwała dzieła Stalina, który przecież rękami NKWD więził Broniewskiego ${ }^{40}$, oznaczała dla poety podziw dla postępu ZSSR i oswobodzenia Polski z rąk nazistów (Urbanek 2011: 276). Cierpienie własne mógł on uznać za mały epizod $^{41}$ na drodze do zaprowadzenia ładu społecznego. Po latach apologia Stalina wywoła dezaprobatę ze strony wielu osób ${ }^{42}$. A Broniewski bardzo obawiał się

38 „Broniewski korzystał oczywiście w PRL-u z tych wszystkich przywilejów, jakimi pragnęli go obdarzyć ci, co PRL-em rządzili. Przydzielono mu na początku lat 50-ych willę na Mokotowie, nie odczuwał chyba żadnych życiowych trudności nękających przeciętnego obywatela w owych latach, ale też i przywilejów tych nie bardzo potrzebował" (za: Pryzwan 2011: 56).

${ }^{39} \mathrm{~W}$ jednym z wywiadów mówił: „Nie mogę pracować tak jakbym pragną, gdyż przeszkadza mi praca zarobkowa. Sądzę, że jak na kilkaset tysięcy wydanych w trzynastoleciu tomów i tomików moich poezji, a także przekładów, może się to stwierdzenie wydać paradoksalne” („Express Wieczorny" 1960).

${ }^{40}$ Broniewski ,był wobec historii, wobec tych, którzy ją tworzyli, naprawdę wspaniałomyślny i wielkoduszny. Wybaczał własne krzywdy. Uważał, że powstanie nowy, lepszy świat, więc należy pewne sprawy wykreślić i specjalnie się nimi nie zajmować. To doprowadziło go do różnych niedobrych tekstów, jak Stowo o Stalinie i inne wiersze tego typu" (Pryzw an 2011: 116).

${ }^{41}$ Broniewski pytany o uwięzienie przez NKWD mówił: „Historia tak się toczy, że są epizody, ale jest też jakiś większy wymiar. Trzeba mimo wszystko wierzyć w świetlaną przyszłość" (za: Pryzwan 2011: 117).

42 „Broniewskiemu, który umiał walczyć z bronią w ręku, kawalerowi krzyża Virtuti Militari, który siedział za swoje poglądy w więzieniach sanacyjnej Polski i stalinowskiej Rosji, odmówiono munduru w 1939 r. i potem w Palestynie, oskarżając go o komunizm. Skundlona «Warszawka», gdy 
odrzucenia, utraty kontaktu z ludźmi. Jego zachowanie cechowało poszukiwanie uznania, a czasem prawdy o sobie i swojej twórczości. Stąd lubił spotykać się z młodymi literatami ${ }^{43}$. W jego domu gościł na przykład Ryszard Kapuściński, który poświęcił Broniewskiemu wiersz przechowywany dziś w archiwum muzeum poety. Do końca życia odczuwał ogromne pragnienie kontaktów z innymi, o czym po śmierci poety opowiadał Władysław Ogniow ${ }^{44}$. Broniewski spotykał się z uznaniem, ale i z dezaprobatą społeczną, ciążyły mu bardzo te sprzeczne reakcje. Desperacko broniąc się przed osamotnieniem odczuwanym w nocy, wybierał na przykład kolejne numery telefonów i dzwonił do znajomych, co sam opisał w wierszu: „Mówią, że dzwonię czasem/ O nieodpowiedniej porze -/ No a jeśli śmierć koło mnie hasa,/ Jeśli... kto wie? - a może [...]/ I ucieczka do telefonu, /nie wszystkie się dają odebrać./ Nie chcę, nie chcę utonąć,/ proszę o miłość - żebrak" (Broniewski 2016: 620).

Mit odrzucenia artysty, zdaniem Mariana Golki, mówi o jego samotności, będącej wynikiem dezaprobaty społecznej. Otoczenie odrzucając dzieła twórcy, odrzuca też jego samego. Owo odrzucenie może mieć wymiar ekonomiczny, społeczny i moralny (Golka 2012: 211). Dla Broniewskiego największym zagrożeniem było odrzucenie moralne.

\section{Czlowiek samotny i spontaniczny}

Moim zdaniem, na wszystkich etapach drogi twórczej i życiowej Broniewskiemu towarzyszyło niezrozumienie. Może dziwić stwierdzenie, że naczelny poeta PRL był samotny. Istnieją jednak na to dowody nie tylko w postaci wierszy i zapisków. Andrzej Braun wspominał:

Doskonale pamiętam smutek na jego twarzy. Często łzawił się i płakał. Nie był płaczliwy, nie były to także łzy pijackie. Po prostu łatwo się wzruszał. Zapamiętałem go jako smutnego i samotnego mężczyznę. Był oczywiście bardzo popularny i modny, ale nie miał wielu przyjaciół w środowisku literackim. Bardzo często siedział w kawiarni Domu Literatury samotnie. Nie

im już Stalina zabrakło, poematu o Stalinie mu nie wybaczyła..." - wspominał Bohdan Drozdowski, przyjaciel Broniewskiego (Pry zw an 2011: 227).

${ }^{43}$ „Lubił młodych. Łatwo i nie z piedestału wieszcza nawiązywał z nimi kontakty, przyjaźnie. Brakowało mu szczerości, a chciał ją mieć. Szukał prawdy o swojej poezji. Szukał potwierdzenia swojej twórczości przez otoczenie - nie był z nią nigdy sam na sam, oddawał ją bez reszty innym na własność" - wspominała Alicja Lisiecka (za: Pry zw an 2011: 228)

44 „Niedługo przed śmiercią w roku 1961, niewiele przed zgonem Broniewskiego, odwiedziłem go w Warszawie w szpitalu przy ulicy Hożej. Chciwie wypytywał o naszych młodych, zdumiewając się: Jakaż kohorta talentów! Lecz nieustannie myśl Broniewskiego nawracała do jednej sprawy: jak trudno znieść oderwanie od ludzi. Długo już chorował. Wszelkie zdarzenia zachodzące w świecie i rodzimej Polsce poznawał tylko z gazet. Wszystko go interesowało i pobudzało... Wszakże kierowałem rozmowę wciąż ku poezji. Tu zmieniał się, promieniejąc wewnętrznym światłem" (za: Pryzwan 2011: 343). 
pamiętam, żeby ktoś się przysiadał, podlizywał czy rozmawiał z nim, a przecież Władek był wówczas najznaczniejszą postacią naszej literatury! (za: Pryzwan 2011: 123).

Z kolei Matylda Wełna-Klonowiecka, która spotkała Broniewskiego w bułgarskim kurorcie we wrześniu 1960 roku, przedstawiła w swoich wspomnieniach o poecie przejmujący i niezwykle plastyczny obraz jego samotności:

Broniewski był milczący i samotny wśród tego rozbawionego thumu - patrzył godzinami na morze lub czytał. Widziałam go w białej koszuli z zawiniętymi rękawami i w jasnych spodniach, przechadzającego się wokół domu, gdzie trawniki dosłownie kipiały od kwiatów, widziałam go w barze - i tańczącego. Miewał podobno i złe chwile; potrafił, jak mi w dyskrecji opowiadano - iść środkiem autostrady, nie zwracając uwagi na ruch pojazdów. Może to bunt wewnętrzny, przeczucie śmierci w kontraście z tym bujnym życiem dookoła? (za: Pryzwan 2011: 223).

Inny, równie plastyczny obraz Broniewskiego pokazany przez Klonowiecką przywodzi na myśl romantyczne dzieło wielkiego niemieckiego malarza Caspera Friedricha pt. Wędrowiec spogladajacy ponad morze mgly ${ }^{45}$. Ten obraz samotnego poety obserwującego na cyplu ptaki jest wręcz archetypiczny ${ }^{46}$. Ilustrację podejmowanej tu kwestii stanowi też relacja opowiadająca o tym, jak spontaniczny Broniewski chciał samotnie obcować z duchem bohatera swojego słynnego wiersza pt. Elegia o Ludwiku Waryńskim. Półtora roku przed własną śmiercią zwiedzał z grupą polskich poetów Leningrad. Stanisław Grochowiak tak to wspominał:

Był lipiec 1960 roku. Grupa poetów polskich zwiedzała Leningrad. Zgodnie z koleją programu trafiliśmy wreszcie do Pietropawłowskiej Twierdzy. [...] Broniewski był niespokojny i niecierpliwy. To było jedyne, co go w tamtej chwili obchodziło naprawdę: cela Ludwika Waryńskiego, poprosił, abyśmy zaczekali na zewnątrz celi. Sam wszedł, widzieliśmy go przez uchylone drzwi, jak stał do nas tyłem nieruchomy, barczysty, o bezwładnie opuszczonych rękach. Po kilku minutach odwrócił się i brutalnym ruchem rozmazał łzy na twarzy. Oglądałem płacz nie twórcy, który sentymentalnym gestem chce uzupełnić swoje dzieło, ale płacz człowieka, który wciąż jeszcze nie może się uspokoić. [...] Sprawa, dla której wiersz powstał, nigdy nie przestawała dręczyć Broniewskiego osobiście. Będąc z wyboru marksistą, na historię patrzył oczyma romantyków - jak na pasmo krwawych wydarzeń ludzkich, których rangę wyznacza skala cierpienia i wzniosłości, a z których nawet najbardziej odległe obciążają również i nasze sumienia (,Kultura” 1967).

45 „Któregoś dnia na plażę nadleciało ogromne stado żurawi. Obserwowałam ożywienie poety. Przyglądał się tej chmarze kołującego ptactwa łapczywie i długo, wyraźnie poruszony. Ujrzałam go na najwyższym cyplu, samotnie obserwującego ten mały szkwał. I takim właśnie, samotnym i uporczywie obserwującym wszystko dookoła, a przede wszystkim niesłychanie zmienne, niedające się ująć w żadne określenie Morze Czarne, zapamiętałam Broniewskiego..." (za: Pryzwan 2011: 224).

${ }^{46}$ Andrzej Osęka, omawiając mit samotności, wskazuje na powracający motyw małej sylwetki człowieka na skale, u jego stóp jeziora, lasy, wokół - góry, nad nim niebo. „On sam zamarły, zawieszony w ogromnej przestrzeni, między niebem a ziemią. Ma przed sobą wszechświat, przedmiot kontemplacji, teren przyszłego działania znajduje się ponad miastem, pejzażem, ludźmi” (Golka 2012: 106). 


\section{Zamiast podsumowania}

Po śmierci Broniewskiego, która miała miejsce 10 lutego 1962 roku, na pogrzeb poety cztery dni później zaczęły zjeżdżać do Warszawy autokary z całej Polski. Tłumy ludzi stały w kolejce do Pałacu Prymasowskiego, gdzie była wystawiona trumna ze zwłokami poety i stały warty honorowe ${ }^{47}$. Wedle propagandowej „Trybuny Ludu”, w dzień pogrzebu na spotkaniach w szkołach, zakładach pracy, domach kultury, zgromadzeni licznie ludzie słuchali wierszy Władysława Broniewskiego. Kobiety klękały przed trumną swego ukochanego poety, jak donosił wówczas „Express Wieczorny” (1962). Podobno słychać było płacz, a czasem deklamację wierszy. Niezależnie, czy był to spektakl wyreżyserowany przez władze czy spontaniczne zachowanie robotniczych tłumów, trwająca ponad pół wieku osobista, niespokojna rozmowa poety z Historią dobiegła końca. Broniewski, który na swojej twórczej i życiowej drodze podjął tyle sprzecznych ról, zobowiązań i obrósł tyloma mitami, znalazł się ,po drugiej stronie lustra”. Opisywane przeze mnie odsłony jego romantycznej postawy artystycznej i życiowej to zarówno znane społecznie i wykorzystywane legendy (rewolucjonisty, socjalisty, naznaczonego wielkim cierpieniem osobistym), jak i mniej znane szerszemu ogółowi (legionisty, piewcy ustroju, ale i buntownika, artysty samotnego).

\section{Bibliografia}

Broniewski W. (2013), Stanęła naga..., oprac. W. Bojda, Wydawnictwo Krytyki Politycznej, Warszawa.

Broniewski W. (2014), Pamiętnik 1918-1922, oprac. M. Tramer, Wydawnictwo Krytyki Politycznej, Warszawa.

Broniewski W. (2016), Wybór wierszy, oprac. T. Bujnicki, Ossolineum, Wrocław.

Flatt O. (2011), Opis miasta Łodzi, Wydawnictwo Grako, Łódź.

Golka M. (2012), Socjologia artysty nowożytnego, Uniwersytet Adama Mickiewicza, Poznań.

Leder A. (2014), Prześniona rewolucja, Wydawnictwo Krytyki Politycznej, Warszawa.

Osmańczyk E. (1982), Sprawy Polaków, Wydawnictwo Śląsk, Katowice.

Pryzw an M. (2011), W stowach jestem wszędzie... Wspomnienia o Władystawie Broniewskim, Państwowy Instytut Wydawniczy, Warszawa.

Shore M. (2013), Kawior i popiót, tłum. M Szuster, Świat Książki, Warszawa.

Urbanek M. (2011), Broniewski. Miłość, wódka, polityka, Iskry, Warszawa.

Wejbert-Wąsiewicz E. (2009), Rola artysty w społeczeństwie, „Dwumiesięcznik społeczno-polityczny. Realia i co dalej...”, nr 4 (13), s. 109-120.

47 „Wartę honorową przy trumnie poety pełnili członkowie kierownictwa partii i rządu, członkowie władz naczelnych stronnictw politycznych, organizacji społecznych i młodzieżowych, przedstawiciele Wojska Polskiego, a także pisarze polscy oraz delegacja pisarzy radzieckich przybyłych na pogrzeb” (,Trybuna Ludu” 1962). 


\section{Archiwum Muzeum Wladyslawa Broniewskiego}

List do Halszki Kamockiej z 23.07.1921.

„Express Wieczorny” 1960, 18.07.

„Express Wieczorny” 1962, 15.02.

„Kultura” 1967, 12.02.

„Literatura” 1972, nr 1.

„Trybuna Ludu” 1962, 15.02.

\section{Eliza Czapska}

\section{THE DIALOGUE OF WLADYSŁAW BRONIEWSKI WITH HISTORY MYTHS AND ROLES IN SYMBOLIC IMAGINARIUM OF POLAND}

Summary. The article concerns the life and work of Władysław Broniewski, a poet whose voice was strongly marked in the history of Poland in the interwar period and the times of the Polish People's Republic. It shows the role of the artist's work, which it played in the 20th anniversary and in subsequent years - during the Second World War and in the new social landscape of the PRL up to the present day. Broniewski's intricate artistic and life path has been discussed in the broad context of artistic myths.

Key words: Władysław Broniewski, history, Poland, tragedy, poetry, romanticism, tradition, family, patriotism, socialism, Legions, First World War, interwar, Second World War, PRL, imaginarium, myths and roles of the artist. 